\title{
Work and health conditions of sugar cane workers in Brazil*
}

\author{
CONDIÇÕES DE TRABALHO E SAÚDE DOS TRABALHADORES DO CORTE DA \\ CANA-DE-AÇÚCAR NO BRASIL
}

\author{
CONDICIONES DE TRABAJO Y SALUD DE LOS TRABAJADORES DEL CORTE DE \\ CAÑA DE AZÚCAR EM BRASIL
}

\section{Fernanda Ludmilla Rossi Rocha ${ }^{1}$, Maria Helena Palucci Marziale ${ }^{2}$, Oi-Saeng Hong ${ }^{3}$}

\begin{abstract}
This is an exploratory research, with a quantitative approach, developed with the objective of analyzing the work and of life situations that can offer risks to the workers' health involved in the manual and automated cut of the sugar cane. The sample was composed by 39 sugar cane cutters and 16 operators of harvesters. The data collection occurred during the months of July and August of 2006, by the technique of direct observation of work situations and workers' homes and through interviews semi-structured. The interviews were recorded and later transcribed. Data were analyzed according to Social Ecological Theory. It was observed that the workers deal with multiple health risk situations, predominantly to the risks of occurrence of respiratory, musculoskeletal and psychological problems and work-related accidents due to the work activities. The interaction of individual, social and environmental factors can determine the workers' tendency to falling ill.
\end{abstract}

\section{KEY WORDS}

Occupational health.

Rural workers.

Health promotion.

\section{RESUMO}

Trata-se de uma pesquisa exploratória, com abordagem quantitativa dos dados, realizada no intuito de analisar as situações de trabalho e de vida que podem oferecer riscos à saúde de trabalhadores envolvidos no corte manual e mecanizado da cana-de-açúcar. A amostra foi composta por 39 cortadores de cana e 16 operadores de colhedeiras. A coleta de dados ocorreu nos meses de julho e agosto de 2006, utilizando-se a técnica de observação direta das situações de trabalho e moradia dos trabalhadores, e por meio de entrevistas semi-estruturadas, que foram gravadas e posteriormente transcritas. Os dados foram analisados a partir da Teoria Social Ecológica. Foi constatado que os trabalhadores estão expostos a inúmeras situações de risco à saúde, predominantemente a riscos de ocorrência de problemas respiratórios, osteomusculares e psicológicos. Além disso, estão sujeitos a acidentes de trabalho em decorrência de sua atividade laboral. Constatou-se também que o adoecimento é determinado pela interação de fatores individuais, ambientais e sociais.

\section{DESCRITORES}

Saúde do trabalhador.

Trabalhadores rurais.

Promoção da saúde.

\begin{abstract}
RESUMEN
Se trata de una investigación exploratoria con abordaje cuantitativo de los datos, realizada con la meta de analizar las situaciones de trabajo y de vida que pueden generar riesgos sanitarios a los trabajadores involucrados en el corte manual y mecanizado de la caña de azúcar. La muestra se compuso de 39 cortadores de caña y 16 operadores de cosechadoras. La recolección de datos tuvo lugar en los meses de julio y agosto de 2006, utilizándose la técnica de observación directa de las situaciones de trabajo y residencia de los trabajadores y a través de entrevistas semiestructuradas, las cuales fueron grabadas y posteriormente transcriptas. Los datos fueron analizados a partir de la Teoría Social Ecológica. Se constató que los trabajadores están expuestos a innumerables situaciones de riesgo sanitario, en particular a los riesgos de sufrir problemas respiratorios, osteomusculares y psicológicos, así como accidentes de trabajo derivados de su actividad laboral, y que su posibilidad de enfermar se determina por la interacción de factores individuales, ambientales y sociales.
\end{abstract}

\section{DESCRIPTORES \\ Salud laboral. \\ Trabajadores rurales. \\ Promoción de la salud.}

This paper was extracted from the dissertation "Analysis of risk factors of manual and mechanized sugar cane cutting in Brazil based on Health Promotion" University of São Paulo at Ribeirão Preto, College of Nursing, 2007. ${ }^{1}$ PhD, RN, University of São Paulo at Ribeirão Preto, College of Nursing. Brazil. ferocha@eerp.usp.br ${ }^{2}$ PhD, RN, Occupational Health Nurse, Full Professor, University of São Paulo at Ribeirão Preto, College of Nursing.Brazil. Brasil. marziale@eerp.usp.br ${ }^{3} \mathrm{PhD}, \mathrm{RN}$, Occupational Health Nurse, Associate Professor, University of California, School of Nursing. San Francisco, CA, United States. OiSaeng. Hong@nursing.ucsf.edu

Rev Esc Enferm USP
2010; 44(4):974-9 $\quad \begin{aligned} & \text { Recceived: 02/19/2008 } \\ & \text { Approved: 03/04/2010 }\end{aligned}$




\section{INTRODUCTION}

Brazil has 189 million inhabitants, of which about 90 million are workers and more than 16 million are rural workers $^{(1)}$. In relation to Brazilian agribusiness, the production of sugar cane and alcohol employs around one million Brazilians $^{(2)}$

Rural work is the focus of this study, more specifically the process involving manual and mechanized sugar cane cutting, because of the transformation in the field due to globalization, the Brazilian vocation for agribusiness, and also the poor working conditions to which these workers are subjected, which combine to lead to occupational illnesses.

Brazil is currently the world's largest producer of sugar cane, followed by India and Australia. The state of São Paulo provides approximately $60 \%$ of the national production, while $55 \%$ of its product is transformed into alcohol and $45 \%$ into sugar. About $80 \%$ of the total production of sugar cane is manually cut, though the use of mechanized harvesters has risen significantly in recent years. Machines harvest more than $25 \%$ of the planted area in the state of São Paulo, while state law has established specific deadlines to eradicate the use of burning in sugar cane harvesting ${ }^{(2)}$.

During manual or mechanized cutting, workers are exposed to long daily shifts and to a workplace that presents multiple health-risk situations, which are similar to the risks faced by rural workers in general. These risks represent what can be called a variety of workloads ${ }^{(4)}$ that express patterns of worker bio-psychological exhaustion ${ }^{(3)}$ and have classified as: 1 ) physical loads (i.e. solar radiation, rain, wind, extreme temperatures, noise and vibrations caused by the machines' movements); 2) chemical loads (i.e. dust, soot, pesticide residues); 3) biological loads (i.e. venomous animals); 4) mechanical loads (i.e. accidents, fire risk); 5) physiological loads (i.e. incorrect posture, repetitive movements, night shifts and shift alternation); and 6) emotional loads (accelerated pace of work, constant attention and concentration, absence of regular breaks, monotony, repetitiveness) $)^{(3,5)}$.

\section{OBJECTIVES}

Aiming to investigate the effects of work practices adopted in manual and mechanized sugar cane cutting on workers' health, this study characterizes: the workplace; the manual and mechanized sugar cane cutting activity; and identifies the workers' socio-demographic data, occupational risks, and workers' health problems.

\section{MATERIAL AND METHOD}

The study was initiated after consent was obtained from the directors of the studied sugar mill and approved by the
Ethics Research Committee of the University of São Paulo at Ribeirão Preto, College of Nursing (CEP-EERP/USP - 098/ 2006). Recommendations of Resolution 196 Ethics related to studies involving human subjects were followed ${ }^{(6)}$.

This exploratory study with quantitative approach was based on the hypotheses that human health and well-being are influenced by multiple elements in the physical and social environments, and also by a variety of personal characteristics, which is the main assumption of Social Ecological Theory ${ }^{(7)}$.

\section{Study's setting and data collection}

The study was carried out at a sugar cane mill in the northwest area of São Paulo, Brazil. The mill employed about 4,450 workers, of which around 1,700 were manual sugar cane cutters and 80 were operators of mechanical harvesters. In the harvest of 2005, the total crop area surpassed 44,000 hectares; approximately 4 million tons of sugar cane were harvested, of which $52.2 \%$ were manually harvested and $47.8 \%$ were mechanically harvested.

The sample was composed of 39 manual sugar cane cutters and 16 mechanical harvester operators, both genders. Those who voluntarily consented in participating in the study and signed free and informed consent forms were randomly included in the study until saturation of data was achieved ${ }^{(8)}$.

Data collection was conducted between July and August, 2006. The participants were individually and separately interviewed through structured interviews with openended questions. Bardin's conceptual framework $^{(8)}$ was used to analyze the participants' reports. According to the methodological framework, data were pre-analyzed and initial ideas were organized into a scheme to facilitate the analysis. Then, data were coded and central ideas that emerged from the reports were identified. The main ideas were divided into two large groups that represented the categories of analysis: 1) the perceptions of workers concerning occupational risks; and 2 ) the perceptions of workers concerning health problems.

In addition to the interviews, systematized observation was used to characterize the workplace and work processes involved in sugar cane cutting. Observations were held on six work shifts: in three shifts manual cutting was observed and three, mechanical cutting. The researcher stayed at the sugar cane plantation throughout the entire observation period and analyzed the labor activities managed by workers according to a previously established script using a field diary. Both data collection instruments were submitted to content validation.

Data analysis aimed to achieve understanding of the main health problems of the studied individuals and determine the main risk factors to which worker health is exposed, in light of the assumptions of the Social Ecological Theory $y^{(7)}$. 


\section{RESULTS}

\section{The workplace}

Workers face different climatic conditions in sugar cane plantations, characterized by intense solar radiation during the entire year, concentration of rains in the summer, high temperatures during the spring and summer, and mild and dry winters during the sugar cane harvest period, which is from April to November in the Southeast.

Therefore, workers involved in the manual and mechanized cutting are daily exposed to several factors that pose risks to their health, such as solar radiation, rains, winds, dust from soil, soot from burned sugar cane, extreme temperatures, pesticide residue, and venomous animals.

\section{Workers' individual conditions}

Socio-demographic data are shown in Table 1. The majority of workers $(89.7 \%$ of manual cutters and $100 \%$ of mechanical harvester operators) were male and younger than 40 years of age. Most manual cutters were migrants from the Northeast with a low educational level. Among the mechanical harvester operators, there was a predominance of individuals from the cities in the region, who also had a higher level of education compared to the manual cutters.

The workers live in small towns surrounding the plantations and are transported to the fields in buses. These vehicles are driven by licensed drivers, are totally enclosed, allow each passenger to travel seated, and have separate places to store their working tools, a refrigerator with filtered water, and a reservoir for non-drinkable water, complying with specific laws ${ }^{(9)}$.

Table 1 - Socio-demographic characteristics of workers involved in the manual and mechanized sugar cane cutting. Sugar and alcohol mill in the northwest region of São Paulo, Brazil - 2006

\begin{tabular}{lcccc}
\hline \multirow{2}{*}{ Characteristics } & \multicolumn{2}{c}{ Manual Cutting } & \multicolumn{2}{c}{ Mechanized Cutting } \\
\cline { 2 - 5 } Gender & $\mathbf{N}$ & $\mathbf{\%}$ & $\mathbf{N}$ & $\mathbf{\%}$ \\
Male & & & & \\
Female & 35 & 89.7 & 16 & 100.0 \\
\hline Age (years) & 4 & 10.3 & & \\
$18-25$ & 18 & 46.1 & 7 & 43.7 \\
$26-30$ & 9 & 23.1 & 4 & 25.0 \\
$31-35$ & 2 & 5.1 & 3 & 18.7 \\
$36-40$ & 4 & 10.3 & 1 & 6.3 \\
$41-45$ & 3 & 7.7 & 1 & 6.3 \\
$46-50$ & & & & \\
$51-55$ & 2 & 5.1 & & \\
$56-60$ & 1 & 2.6 & & \\
\hline Education (years) & & & & \\
$0-4$ & 22 & 56.4 & 4 & 25.0 \\
$5-8$ & 15 & 38.5 & 4 & 25.0 \\
$8-11$ & 2 & 5.1 & 8 & 50.0 \\
\hline Origin & & & & 13 \\
Local & 5 & 12.8 & 12.5 \\
Northeast & 33 & 84.6 & 16 & 100.0 \\
Other & 1 & 2.6 & & \\
\hline Total & 39 & 100.0 & & \\
\hline
\end{tabular}

Also complying with legal requirements, workers' houses are simple but masonry construction, with complete water and sewage systems, washable floors, rooms with individual beds, bathrooms with toilet and shower, kitchen with refrigerators and stoves, living room and laundry. A total of eight to ten workers share each house. Single men and women live separately and families also live in separate houses. However, we observed that sugar cane cutters live in minimum survival conditions, in situation of poverty, without any comfort and in poor sanitary conditions.

Most of the manual cutters in this study (71\%) worked for less than six years in this activity; $39 \%$ of men reported cutting more than 11 tons per day, while women reported cutting between seven and ten tons per day. In relation to the harvester operators, $87.5 \%$ had worked up to six years in this function and most of them did not know the daily amount cut by their machines.

\section{Work activity}

\section{Manual cutting}

Manual cutters start their work shift at 7am after they eat breakfast (bread with butter, milk with coffee, and a drink enriched with mineral salts and electrolytes) supplied by the mill. The typical shift ends at 3:20pm and workers are transported to places close to their houses. A day off is taken every five worked days.

When they arrive to the working place, each worker receives a portion of the plantation to cut as designated by the group leader. To manually cut the cane, workers need to bend, which forms an angle less than 90 degrees between their spinal column and lower limbs. With one hand, they hold a bundle of stalks of sugar cane and with the other hand they use a machete to cut the plant very close to the ground. Then, the worker lifts the cut sugar cane bundle of stalks and carries it for about two meters, laying it on piles.

This set of body movements is repeated continuously during the eight-hour shift. This work is extremely exhausting, heavy and repetitive, leading workers to exhaustion by the end of their shift. At the end of the day, each worker identifies his/er cut area and the amount of sugar cane cut is measured by the group leader and registered in the cutter's monthly production.

In order to protect themselves from sun exposure, dust, and soot from burned cane during the manual cut, workers use hats, handkerchiefs protecting their faces and necks, two overlapping long-sleeve shirts and pants. All cutters used Personal Protective Equipment (PPE), such as safety glasses, leather gloves, leather gaiters along the legs and leather boots with iron tips.

The cutters take a one-hour lunch break and their meal typically consists of beans, rice, pasta and flour. Besides the lunch break, other short breaks are taken by the workers throughout their shift to rest. 


\section{The mechanized cut}

On plantations where cane is cut by mechanical harvesters, work is continuous, 24 hours a day in ten-hour shifts. Workers complete half of the harvest working during day shifts and the other half working in night shifts.

The cabins of the mechanical harvesters are totally enclosed. They are $1.75 \mathrm{~m}$ high, $1.20 \mathrm{~m}$ wide, and have ventilation systems (air conditioning) and adjustable seats for height and back inclination, with regulated supports for the elbows. The harvester's operation is coordinated by pedals and levers. The pedals are located on the floor of the cabin forming an angle of 90 degrees in relation to the drivers' legs. The levers are located in front of the seat, between the legs of the operator and sideways to the right, requiring the left hand control the central levers and the right hand be kept on the lateral levers.

Besides having to keep the feet on the pedals and hands on the levers, the operator must also look ahead, maintaining constant attention on the course to be taken, look to the sides to locate the transshipment truck (which follows the harvester on its side and is where cut sugar cane is stored), watch frequently on the rearview mirror, and observe panel of the machine, on which the general conditions such as temperature, oil level and speed rotation of the motor are shown, actions that demand constant attention and concentration.

Unlike from the cutters, mechanical operators stop their activities only when they need to execute a repair or maintenance on the harvesters, such as cleaning the ventilation system, provisioning and changing the cutting knives, when the harvesters present any mechanical problem or in case of overheating. Mechanical operators take advantage of these moments to rest, eat or to satisfy their physiologic needs (using the plantation itself for it). All the breaks must be communicated to the group leader, who authorizes and, oftentimes, goes personally to the place where the machine stopped to verify the problem.

While the sugar cane cutters' pay is based on production, harvester operators receive a fixed wage and, unlike manual cutters, who have one day off every five worked days, mechanical cutters work 11 consecutive days, only resting on the 12th day, and have a daily workload of 10 hours.

\section{Occupational risks in the perception of workers}

A total of $89.7 \%$ of manual cutters stated they are exposed to multiple risks, which are classified according to the frequency they were cited: accidents and respiratory problems are the most noted risks. Occupational accidents result from machete handling and exposure to venomous animals. Respiratory problems are related to constant exposition to soil dust and burned sugar cane soot.

Cutters next identified risks that were related to the effort spent during sugar cane cutting associated with the intense pace of work and strenuous movements demanded. Back problems are listed as the third leading source of occupational risk. In addition to these problems, workers also identified risks related to circulatory problems, mainly heart attacks (which potentially lead to death), elevation of the blood pressure, and musculoskeletal problems in the upper limbs due to the effort expended during sugar cane cutting.

When questioned about the risks from their professional activity, $81.2 \%$ of the mechanical operators reported they believed their job posed a risk to their health. Similar to manual cutters, occupational accidents were considered to be the highest risk among mechanical operators. These included injuries incurred during machine maintenance, falls and collisions with trucks due to sleepiness or other human failure and contact with the electrical system.

Back problems were the second most mentioned risk, related to long periods in a seated position. Other risks reported included breathing problems related to dust, physical injuries due to positioning and repetitive movements in operating the harvesters and the risk of fire due to machines overheating.

Concerning the occurrence of occupational accidents, $33.3 \%$ of the cutters stated they had already had several machete accidents while cutting sugar cane, which caused cuts on the upper and lower limbs, mainly on the hands, legs and feet. During the interviews, workers acknowledged that use of PPE could minimize the risk of accidents.

About $25 \%$ of mechanical harvester operators claimed they had suffered accidents, which involved injuries during machine maintenance (falls and cuts on the upper limbs) and collisions.

\section{Health problems in the perception of workers}

According to one of the group leaders, workers have numerous health problems, but claim not to have them for fear of not being re-hired by the company for future harvests. One worker reported he was under treatment for recently diagnosed depression and another disclosed having chronic pain in his upper limbs.

Regarding workers' perceptions of physical and psychological fatigue, $74.4 \%$ of the manual cutters reported fatigue and body aches at the end of a working day while $17.9 \%$ admitted having mental fatigue.

Half of the mechanical operators admitted feeling body fatigue at the end of the shift while $31.2 \%$ stated they felt mental fatigue, stress or tension due to the 10-hour shift and resting only on the 12 th day.

\section{DISCUSSION}

Results of this study showed that workers involved in manual and mechanized sugar cane cutting deal with mul- 
tiple health risks, which may jointly determine worker's illnesses due to occupational activities. Workers in the manual sugar cane cutting are exposed to the risk of musculoskeletal disorders (mainly in the lumbar region and upper limbs), determined by a set of abrupt and repetitive body movements, intense work rhythm and extreme physical effort $^{(3,10)}$. The repetitive movements and monotony resulting from manual sugar cane cutting make the attention and concentration required for this activity very difficult, which raises the probability of occupational accidents occurring ${ }^{(3)}$. According to the literature, the most frequent occupational accidents for manual cutters are caused by machete handling and bites of venomous animals ${ }^{(11)}$, while accidents for mechanical cutters occurred from collisions and falls during machine maintenance ${ }^{(10)}$.

Another set of health problems for sugar cane workers are respiratory diseases due to constant exposure to soil dust and soot from the burned sugar cane ${ }^{(12)}$. However, mechanical operators were less prone to respiratory problems since most of the time they spend inside enclosed cabins in the harvesters.

Agrochemicals represent another type of environmental risk to workers, especially to the sugar cane cutters. These substances are associated with the occurrence of numerous human health problems such as respiratory diseases, allergic problems and cancer ${ }^{(13)}$.

Poverty is another social factor that can determine the health condition of sugar cane cutters ${ }^{(14)}$. These workers are poor, live in houses that often lack basic sanitation and tap water, in poor hygienic conditions; their nutritional standards do not meet their individual organic needs; and merely curative medical care is provided by the public health system.

The lack of basic sanitation and environmental hygiene in the places where the sugar cane cutters live, as well as changes in the individuals' nutritional condition, can affect their immunological condition and facilitate infections and the transmission of diseases ${ }^{(15)}$. Moreover, poverty reflects their vulnerable existence, risks, lack of security, and privation of health, education, income, appropriate living conditions, decent work, rights, social participation and status, and especially human dignity.

Unlike the manual cutters, mechanical harvester operators are more exposed to psychological loads due to work. Their work requires repetitive and monotonous activities, which demand constant attention and concentration, potentially leading to psychological problems such as stress and mental fatigue ${ }^{(16)}$.

Operators also are exposed to machine noise and vibrations and work 10-hour shifts with no regular breaks for 11 days in a row, resting only on the 12th day. As shown by the analysis of the interviews, mental fatigue causes a decrease in workers' threshold of attention span and concentration, predisposing them to the occurrence of accidents.
In addition to psychological problems, mechanical harvester operators are also at the risk of being affected by musculoskeletal disorders due to their seated position throughout their shift, without regular breaks or the possibility of stretching or extending their limbs.

Work remuneration is an additional factor that affects worker illness. Paid on the basis of their production, the cutters try to increase their work pace in order to ensure higher payments and also the maintenance of their jobs in subsequent harvests, neglecting the limits of their own bodies and exposing themselves to constant work overloads and risk to their health. The relation between the form of remuneration and intensification of the work pace is considered the main cause of death in the cases of 10 sugar cane cutters who died in the state of São Paulo in $2005^{(17)}$.

Manual sugar cane cutters earn their wage according to production and mechanical harvester operators receive a fixed wage, however, harvester operators are also subjected to an intense work pace determined by the machine, which denies the worker control of his/her own work rhythm. As the machine is only stopped when it needs maintenance, fuel, cleaning, overheats or when there are no sugar cane transshipment trucks available; these are the only points at which operators ask for permission from their group leaders to stop their job and undertake personal activities (meals, satisfaction of physiological needs) or rest.

This observed occurrence is evidence of the submission of workers to the work process used in mechanized cutting, which aims for high productivity, optimization of time and resources available, and cost reduction, to achieve high profitability. This is the subordination of work to the rationale of capital valuation ${ }^{(18)}$.

In relation to the workers' perceptions, the cutters and harvester operators identified the main occupational risks and health problems to which they are exposed due to manual and mechanized sugar cane cutting, represented by work-related accidents, musculoskeletal disorders, respiratory and psychological problems, as described in the literature. It was evident that they accepted inadequate living and working conditions offered by the employers and did not adopted any health promotion behavior.

\section{CONCLUSION}

The conclusion is that the health and illnesses of the sugar cane workers studied is determined by the interaction of individual, social and environmental factors, which is the main assumption of the Social Ecological Theory. This theory explains the complexities and interdependencies between socio-economic, cultural, political, environmental, organizational, psychological, and biological factors as determinants of health. It also proposes that any individual behavior is based on and influenced by numerous other systems and groups. Hence, the theoretical approach used 
in this study permitted the identification of multidimensional determinants of the health of sugar cane workers.

Given the complexity of the problem studied, further research aimed at developing health promotion and mini-

\section{REFERENCES}

1. Instituto Brasileiro de Geografia e Estatística (IBGE). Pesquisa Nacional por Amostragem de Domicílios: síntese de indicadores, 2007 [texto na Internet]. Rio de Janeiro; 2007. [citado 2008 nov. 15]. Disponível em: http://www.ibge.gov.br/home/estatistica/ populacao/trabalhoerendimento/pnad2007/comentarios2007.pdf

2. União da Agroindústria Canavieira de São Paulo. Safra paulista de cana-de-açúcar cresce mais de $8 \%$. Informação UNICA. 2007;75(9):1.

3. Alessi NP, Scopinho RA. A saúde do trabalhador do corte da cana-de-açúcar. In: Alessi NP, Palocci Filho A, Pinheiro SA, Scopinho RA, Silva GB. Saúde e trabalho no Sistema Único de Saúde. São Paulo: Hucitec; 1994. p.121-51.

4. Laurell AC, Noriega M. Processo de produção de saúde: trabaIho e desgaste operário. São Paulo: Hucitec; 1989.

5. Scopinho RA, Edi F, Vian CEF, Silva PRC. Novas tecnologias e saúde do trabalhador: a mecanização do corte da cana-de-açúcar. Cad Saúde Pública. 1999;1(15):147-161.

6. Conselho Nacional de Saúde. Resolução n. 196, de 10 de outubro de 1996. Dispõe sobre diretrizes e normas regulamentadoras de pesquisas envolvendo seres humanos. Bioética. 1996;4(2 Supl):15-25.

7. Stokols D. Translating social ecological theory into guidelines for community health promotion. Am J Health Promot. 1996;10(4):282-98.

8. Bardin L. Análise de conteúdo. Lisboa: Edições 70; 1977.

9. Brasil. Ministério do Trabalho. Portaria n. 86, de 3 de março de 2005. Norma Reguladora de Segurança e Saúde no Trabalho na Agricultura, Pecuária, Silvicultura, Exploração Florestal e Aqüicultura [legislação na Internet]. Brasília; 2005. [citado 2008 nov. 20]. Disponível em: http://www.senar.org.br/arrecadacao/ fund_legal/PORTARIA86.PDF mizing occupational risks and health problems to which workers involved in the manual and mechanized sugar cane cutting industry in Brazil are exposed, is needed.

10. Alessi NP, Navarro VL. Saúde e trabalho rural: o caso dos trabalhadores da cultura canavieira na região de Ribeirão Preto, São Paulo, Brasil. Cad Saúde Pública. 1997;13 Supl 2):111-21.

11. Teixeira MLP, Freitas RMV. Acidentes do trabalho rural no interior paulista. São Paulo Perspect. 2003;17(2):81-90.

12. Ribeiro H. Queimadas de cana-de-açúcar no Brasil: efeitos à saúde respiratória. Rev Saúde Pública. 2008;42(2):370-6.

13. Siqueira SL, Kruse MHL. Agrotóxicos e saúde humana: contribuição dos profissionais do campo da saúde. Rev Esc Enferm USP. 2008;42(3):584-90.

14. Rocha FLR, Marziale MHP, Robazzi MLCC. Poverty as a predisposing factor of illness tendencies in sugar cane workers. Rev Lat Am Enferm. 2007;15(n.esp):736-41.

15. World Health Organization (WHO). DAC Guidelines and reference series: poverty and health [text on the Internet]. 2003. [cited $2007 \mathrm{Jul}$ 30]. Available from: http:// whqlibdoc.who.int/publications/2003/9241562366.pdf

16. Scopinho RA. Pedagogia empresarial de controle do trabalho e saúde do trabalhador: o caso de uma usina-destilaria da região de Ribeirão Preto [dissertação]. São Carlos: Centro de Educação e Ciências Humanas, Universidade Federal de São Carlos; 1995.

17. Alves F. Por que morrem os cortadores de cana? Saúde Soc. 2006;15(3):90-8.

18. Silva JG. Progresso técnico e relações de trabalho na agricultura. São Paulo: Hucitec; 1981. 